\title{
The impact of information and communication technologies (ICT) on agility, operating, and economical performance of supply chain
}

\author{
García-Alcaraz, J.L., ${ }^{a}$, Maldonado-Macías, A.A. ${ }^{a}$, Alor-Hernández, G. ${ }^{b}$, Sánchez-Ramírez, C. ${ }^{b}$ \\ ${ }^{a}$ Department of Industrial and Manufacturing Engineering, Universidad Autónoma de Ciudad Juárez, Mexico \\ ${ }^{b}$ Division of Research and Graduate Studies, Instituto Tecnológico de Orizaba, Veracruz, Mexico
}

\begin{abstract}
A B S T R A C T
Information and communication technologies (ICT) are widely used in supply chain (SC) due to their effects on both economic performance and operational agility. This paper proposes a structural equation model integrating 17 items into four latent variables: ICT, SC agility, operating performance, and economic performance. Data analysed in the model were gathered through a questionnaire administered to 306 managers of Mexican maquiladoras. Likewise, we used statistical software WarpPLS $5 \AA$, which is based on partial least squares algorithms, to assess the six hypotheses established in the model. Such hypotheses were validated with a $95 \%$ confidence level, and values were standardized to avoid problems regarding the measurement scale. Findings demonstrate that ICT have a positive direct impact on the other three analysed latent variables, which together account for $63 \%$ of the variability of SC economic performance. Similarly, we found that ICT can explain up to $40 \%$ of the variability of SC agility.
\end{abstract}

(c) 2017 PEI, University of Maribor. All rights reserved.

\begin{tabular}{l} 
A R T I C L E I N F O \\
\hline Keywords: \\
Supply chain \\
Information and communication \\
technologies (ICT) \\
Supply chain agility \\
Supply chain flexibility \\
Economic performance \\
*Corresponding author: \\
jorge.garcia@uacj.mx \\
(García-Alcaraz, J.L.) \\
Article history: \\
Received 24 July 2016 \\
Revised 26 November 2016 \\
Accepted 4 January 2017
\end{tabular}

\section{ARTICLE INFO}

Keywords:

Supply chain

Information and communication

technologies (ICT)

Supply chain agility

Supply chain flexibility

Economic performance

*Corresponding author:

jorge.garcia@uacj.mx

(Carcía-Alcaraz, J.L.)

Accepted 4 January 2017

\section{References}

[1] Ketikidis, P.H., Koh, S.C.L., Dimitriadis, N., Gunasekaran, A., Kehajova, M. (2008). The use of information systems for logistics and supply chain management in South East Europe: Current status and future direction, Omega, Vol. 36, No. 4, 592-599, doi: 10.1016/i.omega.2006.11.010.

[2] Mensah, P., Merkuryev, Y., Longo, F. (2015). Using ICT in Developing a Resilient Supply Chain Strategy, Procedia Computer Science, Vol. 43, 101-108, doi: 10.1016/i.procs.2014.12.014.

[3] García-Alcaraz, J.L., Maldonado-Macías, A.A. (2016). Just-in-time elements and benefits, Series Management and Industrial Engineering, Springer International Publishing, New York, USA, doi: 10.1007/978-3-319-25919-2.

[4] Martínez-Loya, V., García-Alcaraz, J.L., Díaz-Reza, J.R., Marquez-Gayosso, D.G. (2017). The Impact of ICT on Supply Chain Agility and Human Performance, In: Leal-Jamil, G., Lucas-Soares, A., Magalhães-Pessoa, C.R. (eds.), Handbook of Research on Information Management for Effective Logistics and Supply Chains, IGI-Global, Hershey, PA, USA, 180-198, doi: 10.4018/978-1-5225-0973-8.ch010.

[5] Caridi, M., Moretto, A., Perego, A., Tumino, A. (2014). The benefits of supply chain visibility: A value assessment model, International Journal of Production Economics, Vol. 151, 1-19, doi: 10.1016/j.ijpe.2013.12.025.

[6] Zhang, A.N., Goh, M., Meng, F. (2011). Conceptual modelling for supply chain inventory visibility, International Journal of Production Economics, Vol. 133, No. 2, 578-585, doi: 10.1016/i.ijpe.2011.03.003.

[7] Yu, M.-C., Goh, M. (2014). A multi-objective approach to supply chain visibility and risk, European Journal of Operational Research, Vol. 233, No. 1, 125-130, doi: 10.1016/j.ejor.2013.08.037.

[8] Williams, B.D., Roh, J., Tokar, T., Swink, M. (2013). Leveraging supply chain visibility for responsiveness: The moderating role of internal integration, Journal of Operations Management, Vol. 31, No. 7-8, 543-554, doi: 10.1016/j.jom.2013.09.003. 
[9] Zhang, H.P. (2015). An agent-based simulation model for supply chain collaborative technological innovation diffusion, International Journal of Simulation Modelling, Vol. 14, No. 2, 313-324, doi: 10.2507/IJSIMM14(2)CO6.

[10] Sukati, I., Hamid, A.B., Baharun, R., Yusoff, R.M., Anuar, M.A. (2012). The Effect of Organizational Practices on Supply Chain Agility: An Empirical Investigation on Malaysia Manufacturing Industry, Procedia - Social and Behavioral Sciences, Vol. 40, 274-281, doi: 10.1016/i.sbspro.2012.03.191.

[11] Kesen, S.E., Kanchanapiboon, A., Das, S.K. (2010). Evaluating supply chain flexibility with order quantity constraints and lost sales, International Journal of Production Economics, Vol. 126, No. 2, 181-188, doi: 10.1016/j.ijpe.2010.03.006.

[12] Gosling, J., Purvis, L., Naim, M.M. (2010). Supply chain flexibility as a determinant of supplier selection, International Journal of Production Economics, Vol. 128, No. 1, 11-21, doi: 10.1016/j.ijpe.2009.08.029.

[13] Sabbaghi, N., Sheffi, Y., Tsitsiklis, J.N. (2014). Allocational flexibility in constrained supply chains, International Journal of Production Economics, Vol. 153, 86-94, doi: 10.1016/i.ijpe.2014.01.014.

[14] Wallace, S.W., Choi, T.-M. (2011). Flexibility, information structure, options, and market power in robust supply chains, International Journal of Production Economics, Vol. 134, No. 2, 284-288, doi: 10.1016/j.ijpe.2009.11.002.

[15] Seebacher, G., Winkler, H. (2015). A capability approach to evaluate supply chain flexibility, International Journal of Production Economics, Vol. 167, 177-186, doi: 10.1016/i.ijpe.2015.05.035.

[16] Acar, A.Z., Uzunlar, M.B. (2014). The effects of process development and information technology on time-based supply chain performance, Procedia - Social and Behavioral Sciences, Vol. 150, 744-753, doi: 10.1016/j.sbspro. 2014.09.044.

[17] Costantino, N., Dotoli, M., Falagario, M., Fanti, M.P., Mangini, A.M. (2012). A model for supply management of agile manufacturing supply chains, International Journal of Production Economics, Vol. 135, No. 1, 451-457, doi: 10.1016/i.ijpe.2011.08.021.

[18] Hudnurkar, M., Jakhar, S., Rathod, U. (2014). Factors affecting collaboration in supply chain: A literature review, Procedia - Social and Behavioral Sciences, Vol. 133, 189-202, doi: 10.1016/j.sbspro.2014.04.184.

[19] Kisperska-Moron, D., de Haan, J. (2011). Improving supply chain performance to satisfy final customers: "Leagile" experiences of a polish distributor, International Journal of Production Economics, Vol. 133, No. 1, 127134, doi: 10.1016/j.ijpe.2009.12.013.

[20] Rouyendegh, B.R., Baç, U., Erkan, T.E. (2014). Sector selection for ERP implementation to achieve most impact on supply chain performance by using AHP-TOPSIS hybrid method, Tehnički vjesnik - Technical Gazette, Vol. 21, No. 5, 933-937.

[21] Correa-Espinal, A., Gómez-Montoya, R., (2009). Information technologies in supply chain management, DYNA, Vol. 76, No. 157, 37-48.

[22] Mensah, P., Merkuryev, Y., Longo, F. (2015). Using ICT in developing a resilient supply chain strategy, Procedia Computer Science, Vol. 43, 101-108, doi: 10.1016/i.procs.2014.12.014.

[23] de Treville, S., Shapiro, R.D., Hameri, A.-P. (2004). From supply chain to demand chain: The role of lead time reduction in improving demand chain performance, Journal of Operations Management, Vol. 21, No. 6, 613-627, doi: 10.1016/i.jom.2003.10.001.

[24] Warren Liao, T., Chang, P.C. (2010). Impacts of forecast, inventory policy, and lead time on supply chain inventory - A numerical study, International Journal of Production Economics, Vol. 128, No. 2, 527-537, doi: 10.1016/ j.ijpe.2010.07.002.

[25] Li, Y., Xu, X., Ye, F. (2011). Supply chain coordination model with controllable lead time and service level constraint, Computers \& Industrial Engineering, Vol. 61, No. 3, 858-864, doi: 10.1016/i.cie.2011.05.019.

[26] Leber, M., Weber, C., Adam, F., Leber, M. (2014). Mobile application as an innovative supply chain concept and the impact of social capital, International Journal of Simulation Modelling, Vol. 13, No. 2, 135-146, doi: 10.2507/ IJSIMM13(2)1.255.

[27] Pan, J.-N., Nguyen, H.T.N. (2015). Achieving customer satisfaction through product-service systems, European Journal of Operational Research, Vol. 247, No. 1, 179-190, doi: 10.1016/j.ejor.2015.05.018.

[28] Dehning, B., Richardson, V.J., Zmud, R.W. (2007). The financial performance effects of IT-based supply chain management systems in manufacturing firms, Journal of Operations Management, Vol. 25, No. 4, 806-824, doi: 10.1016/i.jom.2006.09.001.

[29] Elgazzar, S.H., Tipi, N.S., Hubbard, N.J., Leach, D.Z. (2012). Linking supply chain processes' performance to a company's financial strategic objectives, European Journal of Operational Research, Vol. 223, No. 1, 276-289, doi: 10.1016/i.ejor.2012.05.043.

[30] Kisperska-Moron, D., Swierczek, A. (2009). The agile capabilities of Polish companies in the supply chain: An empirical study, International Journal of Production Economics, Vol. 118, No. 1, 217-224, doi: 10.1016/j.ijpe. 2008.08.019.

[31] Ngai, E.W.T., Chau, D.C.K., Chan, T.L.A. (2011). Information technology, operational, and management competencies for supply chain agility: Findings from case studies, The Journal of Strategic Information Systems, Vol. 20, No. 3, 232-249, doi: 10.1016/i.jsis.2010.11.002.

[32] Kanellou, A., Spathis, C. (2013). Accounting benefits and satisfaction in an ERP environment, International Journal of Accounting Information Systems, Vol. 14, No. 3, 209-234, doi: 10.1016/j.accinf.2012.12.002.

[33] Teittinen, H., Pellinen, J., Järvenpää, M. (2013). ERP in action - Challenges and benefits for management control in SME context, International Journal of Accounting Information Systems, Vol. 14, No. 4, 278-296, doi: 10.1016/j.accinf.2012.03.004.

[34] Silvestre, B.S. (2015). Sustainable supply chain management in emerging economies: Environmental turbulence, institutional voids and sustainability trajectories, International Journal of Production Economics, Vol. 167, 156169, doi: 10.1016/i.ijpe.2015.05.025. 
[35] Gligor, D.M., Esmark, C.L., Holcomb, M.C. (2015). Performance outcomes of supply chain agility: When should you be agile?, Journal of Operations Management, Vol. 33-34, 71-82, doi: 10.1016/i.jom.2014.10.008.

[36] Yang, J. (2014). Supply chain agility: Securing performance for Chinese manufacturers, International Journal of Production Economics, Vol. 150, 104-113, doi: 10.1016/j.ijpe.2013.12.018.

[37] Yusuf, Y.Y., Gunasekaran, A., Musa, A., Dauda, M., El-Berishy, N.M., Cang, S. (2014). A relational study of supply chain agility, competitiveness and business performance in the oil and gas industry, International Journal of Production Economics, Vol. 147, Part B, 531-543, doi: 10.1016/j.ijpe.2012.10.009.

[38] Sanzo, M.J., Vázquez, R. (2011). The influence of customer relationship marketing strategies on supply chain relationships: The moderating effects of environmental uncertainty and competitive rivalry, Journal of Businessto-Business Marketing, Vol. 18, No. 1, 50-82, doi: 10.1080/10517121003717799.

[39] Yu, W., Jacobs, M.A., Salisbury, W.D., Enns, H. (2013). The effects of supply chain integration on customer satisfaction and financial performance: An organizational learning perspective, International Journal of Production Economics, Vol. 146, No. 1, 346-358, doi: 10.1016/i.ijpe.2013.07.023.

[40] Li, Y., Ye, F., Lin, Q. (2015). Optimal lead time policy for short life cycle products under Conditional Value-at-Risk criterion, Computers \& Industrial Engineering, Vol. 88, 354-365, doi: 10.1016/i.cie.2015.07.011.

[41] Kaloxylos, A., Wolfert, J., Verwaart, T., Terol, C.M., Brewster, C., Robbemond, R., Sundmaker, H. (2013). The use of future internet technologies in the agriculture and food sectors: Integrating the supply chain, Procedia Technology, Vol. 8, 51-60, doi: 10.1016/j.protcy.2013.11.009.

[42] Harris, I., Wang, Y., Wang, H. (2015). ICT in multimodal transport and technological trends: Unleashing potential for the future, International Journal of Production Economics, Vol. 159, 88-103, doi: 10.1016/i.ijpe.2014.09.005.

[43] Lin, C., Chow, W.S., Madu, C.N., Kuei, C.-H., Yu, P.P. (2005). A structural equation model of supply chain quality management and organizational performance, International Journal of Production Economics, Vol. 96, No. 3, 355365, doi: 10.1016/i.ijpe.2004.05.009.

[44] Chung, K.-J., Liao, J.-J., Ting, P.-S., Lin, S.-D., Srivastava, H.M. (2015). The algorithm for the optimal cycle time and pricing decisions for an integrated inventory system with order-size dependent trade credit in supply chain management, Applied Mathematics and Computation, Vol. 268, 322-333, doi: 10.1016/i.amc.2015.06.039.

[45] Yusuf, Y.Y., Gunasekaran, A., Adeleye, E.O., Sivayoganathan, K. (2004). Agile supply chain capabilities: Determinants of competitive objectives, European Journal of Operational Research, Vol. 159, No. 2, 379-392, doi: 10.1016/i.ejor.2003.08.022.

[46] Musa, A., Gunasekaran, A., Yusuf, Y. (2014). Supply chain product visibility: Methods, systems and impacts, Expert Systems with Applications, Vol. 41, No. 1, 176-194, doi: 10.1016/i.eswa.2013.07.020.

[47] Disney, S.M., Naim, M.M., Potter, A. (2004). Assessing the impact of e-business on supply chain dynamics, International Journal of Production Economics, Vol. 89, No. 2, 109-118, doi: 10.1016/S0925-5273(02)00464-4.

[48] Ram, J., Corkindale, D., Wu, M.-L. (2014). ERP adoption and the value creation: Examining the contributions of antecedents, Journal of Engineering and Technology Management, Vol. 33, 113-133, doi: 10.1016/i.jengtecman. 2014.04.001.

[49] Hingley, M., Lindgreen, A., Grant, D.B. (2015). Intermediaries in power-laden retail supply chains: An opportunity to improve buyer-supplier relationships and collaboration, Industrial Marketing Management, Vol. 50, 78-84, doi: 10.1016/i.indmarman.2015.05.025.

[50] Bevilacqua, M., Ciarapica, F.E., Giacchetta, G. (2009). Business process reengineering of a supply chain and a traceability system: A case study, Journal of Food Engineering, Vol. 93, No. 1, 13-22, doi: 10.1016/j.jfoodeng. 2008.12.020.

[51] Borgianni, Y., Cascini, G., Rotini, F. (2015). Business process reengineering driven by customer value: A support for undertaking decisions under uncertainty conditions, Computers in Industry, Vol. 68, 132-147, doi: 10.1016/j.compind.2015.01.001.

[52] Blome, C., Schoenherr, T. (2011). Supply chain risk management in financial crises - A multiple case-study approach, International Journal of Production Economics, Vol. 134, No. 1, 43-57, doi: 10.1016/i.ijpe.2011.01.002.

[53] Gligor, D.M., Holcomb, M.C., Feizabadi, J. (2016). An exploration of the strategic antecedents of firm supply chain agility: The role of a firm's orientations, International Journal of Production Economics, Vol. 179, 24-34, doi: 10.1016/i.ijpe.2016.05.008.

[54] Hair Jr, J.F., Ringle, C.M., Sarstedt, M. (2013). Partial least squares structural equation modeling: Rigorous applications, better results and higher acceptance, Long Range Planning, Vol. 46, No. 1-2, 1-12, doi: 10.1016/j.lrp.2013.01.001.

[55] García-Alcaraz, J.L., Maldonado, A.A., Iniesta, A.A., Robles, G.C., Hernández, G.A. (2014). A systematic review/survey for JIT implementation: Mexican maquiladoras as case study, Computers in Industry, Vol. 65, No. 4, 761-773, doi: $10.1016 /$ i.compind.2014.02.013.

[56] Avelar-Sosa, L., García-Alcaraz, J.L., Castrellón-Torres, J.P. (2014). The effects of some risk factors in the supply chains performance: A case of study, Journal of Applied Research and Technology, Vol. 12, No. 5, 958-968, doi: 10.1016/S1665-6423(14)70602-9.

[57] Kock, N., Verville, J., Danesh-Pajou, A., DeLuca, D. (2009). Communication flow orientation in business process modeling and its effect on redesign success: Results from a field study, Decision Support Systems, Vol. 46, No. 2 , 562-575, doi: 10.1016/i.dss.2008.10.002.

[58] Tastle, W.J., Wierman, M.J. (2007). Consensus and dissention: A measure of ordinal dispersion, International Journal of Approximate Reasoning, Vol. 45, No. 3, 531-545, doi: 10.1016/j.ijar.2006.06.024.

[59] Green Jr, K.W., Inman, R.A., Birou, L.M., Whitten, D. (2014). Total JIT (T-JIT) and its impact on supply chain competency and organizational performance, International Journal of Production Economics, Vol. 147, Part A, 125135, doi: 10.1016/i.ijpe.2013.08.026. 
[60] Merschmann, U., Thonemann, U.W. (2011). Supply chain flexibility, uncertainty and firm performance: An empirical analysis of German manufacturing firms, International Journal of Production Economics, Vol. 130, No. 1, 4353, doi: 10.1016/j.ijpe.2010.10.013.

[61] Yang, S., Albert, R., Carlo, T.A. (2013). Transience and constancy of interactions in a plant-frugivore network, Ecosphere, Vol. 4, No. 12, 1-25, doi: 10.1890/ES13-00222.1.

[62] Kock, N. (2013). Using WarpPLS in e-collaboration studies: What if I have only one group and one condition?, International Journal of e-Collaboration, Vol. 9, No. 3, 1-12, doi: 10.4018/jec.2013070101.

[63] Ketkar, M., Vaidya, O.S. (2012). Study of emerging issues in supply risk management in India, Procedia - Social and Behavioral Sciences, Vol. 37, 57-66, doi: 10.1016/j.sbspro.2012.03.275. 


\section{APEM}

\title{
Vpliv informacijskih in komunikacijskih tehnologij (ICT) na agilnost, delovanje in gospodarnost dobavnih verig
}

\author{
García-Alcaraz, J.L. ${ }^{\text {a, }}$, Maldonado-Macías, A.A. ${ }^{\text {a }}$, Alor-Hernández, G. ${ }^{b}$, Sánchez-Ramírez, C. ${ }^{b}$ \\ ${ }^{a}$ Department of Industrial and Manufacturing Engineering, Universidad Autónoma de Ciudad Juárez, Mexico \\ ${ }^{b}$ Division of Research and Graduate Studies, Instituto Tecnológico de Orizaba, Veracruz, Mexico
}

\section{POVZETEK}

Informacijske in komunikacijske tehnologije (angl. ICT) se pogosto uporabljajo v dobavnih verigah (angl. SC), zaradi vpliva na njihovo gospodarnost in agilnost delovanja. Prispevek predlaga model strukturne enačbe, ki vključuje 17 elementov v štiri latentne spremenljivke: ICT, agilnost SC, uspešnost delovanja in gospodarnost. Podatki za analizo so bili zbrani s pomočjo vprašalnika izdanega 306 menedžerjem mehiških izvoznih podjetij. Za ocenitev šestih hipotez določenih v modelu je bila uporabljena programska oprema WarpPLS $5 \AA$, ki temelji na algoritmu delnih najmanjših kvadratov. Hipoteze so bile potrjene s $95 \%$ verjetnostjo, vrednosti pa so bile standardizirane, da bi se izognili težavam povezanim z merilno skalo. Rezultati kažejo, da imajo ICT pozitiven in neposreden vpliv na ostale tri latentne spremenljivke, ki skupaj predstavljajo $63 \%$ variabilnosti gospodarnosti dobavnih verig, in tudi, da ICT predstavljajo $40 \%$ variabilnosti agilnosti dobavnih verig.

(c) 2017 PEI, University of Maribor. All rights reserved.

\section{PODATKI O ČLANKU}

Ključne besede:

Dobavna veriga

Informacijske in komunikacijske

tehnologije (ICT)

Agilnost dobavne verige

Prilagodljivost dobavne verige

Gospodarnost

*Kontaktna oseba:

jorge.garcia@uacj.mx

(García-Alcaraz, J.L.)

Zgodovina članka:

Prejet 24. julija 2016

Popravljen 26. novembra 2016

Sprejet 4. januarja 2017 